\title{
Okul Yöneticilerinin Teknoloji Liderliği Rollerinin Öğretmen Görüşleri Doğrultusunda
}

\section{Değerlendirilmesi*}

\section{Levent DENIZ**, Seher TEKE***}

Öz: Bu araştırmanın amacı resmi ilköğretim ve ortaöğretim kurumlarında görev yapan okul yöneticilerin teknoloji liderliği rollerini öğretmen görüşleri doğrultusunda değerlendirmektir. Öğretmenlerin görüşleri öğretmenlerin cinsiyet, branş, hizmet y1lı, teknoloji ile ilgili eğitim alma durumu, çalıştıkları okul türü, öğretmenlerin okuldaki teknolojik imkânları yeterli bulma düzeylerine, lisansüstü eğitim alıp-almama durumuna göre incelenmiştir. Araştırmada karşılaştırmalı genel tarama modeli kullanılmıştır. Araştırmanın örneklemini 2016-2017 eğitim- öğretim yılında Van ilinde Tuşba, İpekyolu, Edremit ve Erciş ilçelerindeki 16 ilköğretim ve 21 ortaöğretim okulunda görev yapmakta olan 452 öğretmen oluşturmuştur. Araştırmada Sincar (2009) tarafından geliştirilen 5'li likert tipi “Okul Yöneticisinin Teknoloji Liderliği Ölçeği” kullanılmıştır. Araştırma bulgularına göre; öğretmenler okul yöneticilerinin teknoloji liderliği rollerini sergileme düzeylerini “orta” seviyede bulmuştur. Öğretmenlerin yöneticilerinin teknoloji liderliği rollerine ilişkin görüşleri cinsiyete, hizmet yılına, teknoloji ile ilgili eğitim alma durumuna, lisansüstü eğitim alma durumuna, branşa göre farklılaşmamıştır. Öğretmenlerin yöneticilerinin teknoloji liderliği rollerine ilişkin görüşleri okul türüne, okuldaki teknolojik imkânı yeterli bulma düzeyine göre farklılaşmıştır.

Anahtar Kelimeler: Liderlik, teknoloji liderliği, okul yöneticisi

\footnotetext{
${ }^{*}$ Bu araştırma Seher Teke'nin Marmara Üniversitesi Eğitim Bilimleri Enstitüsü Eğitim Yönetimi ve Denetimi programında tamamladığı yüksek lisans tezinin bir kısmına dayanmaktadır.

** Prof. Dr., Marmara Üniversitesi Atatürk Eğitim Fakültesi Eğitim Bilimleri Bölümü, ORCID: 0000-0002-5786-215X 1deniz@marmara.edu.tr

*** Öğretmen, MEB, ORCID: 0000-0002-5972-4279, seher 2626@outlook.com,
} 


\title{
An Evaluation of Teacher Views on School Principals' Technology Leadership Roles
}

\begin{abstract}
The aim of this study is to evaluate the 'technology leadership' roles of the administrators at primary and secondary level state schools in accordance with the teachers' views. The study examined the differences of the teachers' views according to their sexes, branches, years of teaching experience, whether they received any training of technology, the type of school they worked at, level of finding technological opportunities satisfactory in school. The study was designed as a comparative general survey model. The sample of the study consisted of 452 teachers working at 16 primary and 21 secondary schools in Van during 2016-2017 years. "School Principals' Technology Leadership Role Scale” developed by Sincar (2009) was used to collect the research data. According to the research findings, the teachers think that the school administrators display their roles of technology leadership at an intermediate level. Moreover, the teachers' views on the administrators' roles of technology leadership do not differ based on sex, years of experience, whether they received any training of technology, branch. However, the teachers' views on the administrators' roles of technology leadership differ considering the type of school and the level they find the technological opportunities satisfactory at their schools.
\end{abstract}

Keyword: Leadership, technology leadership, school administrator 


\section{Giriş}

Teknoloji günümüz dünyasının ayrılmaz bir parçasıdır. Eğitim, kültür, sağlık, bilim, sanat gibi pek çok alanı doğrudan etkilemektedir. Bu alanlardan biri olan eğitimin toplum üzerinde değişim konusunda etkisi yadsınamaz. Bu nedenle teknolojinin çok yaygın kullanıldığg günümüzde öğretimin içinde teknolojinin yer almaması düşünülemez. Özellikle Z kuşağı diye nitelendirdiğimiz teknoloji ile büyüyen bir neslin ortaya çıkması eğitim kurumlarının teknolojiden uzakta kalmasına firsat vermemektedir. $\mathrm{Bu}$ sebeple eğitim kurumların teknolojiye entegrasyonları önemli bir durumdur (Arslan, 2016).

Kişileri toplumun geleceğine hazırlayan eğitim kurumlarında; teknolojinin bir araç olarak okullara girmesi ve materyal olarak kullanılması aşamasında teknolojinin entegrasyonu, eğitim personelinin yetiştirilmesini gerekmektedir (Küplü, 2012). Eğitim personellerinin başında yer alan öğretmenlerin eğitim sisteminin ihtiyaçları doğrultusunda yeterli teknolojik donanıma sahip olması gerekmektedir. Öğretmenlerin teknolojik anlamda yetişmesini ve gelişmesini sağlayacak, onların teknolojiyi öğretme öğrenme süreçlerine uyarlamalarına rehberlik ederek destek verecek kişilerin başında da okul yöneticileri gelmektedir.

Günümüzde bilgi teknolojilerini hızla gelişmesi eğitim camiasını da etkilemiştir. $\mathrm{Bu}$ sebeple okul yöneticilerine yeni bir liderlik vasfı doğmuştur. Okulda teknolojinin kullanımını ve yaygınlaştırılmasını benimseyen teknoloji liderliği rolü günümüz bilgi ve teknoloji çağının önemli bir adımı haline gelmiştir. Çünkü teknolojik gelişmelerden uzak duran bir okul yöneticisi, okulunun değişimlere karşı duyarsız kalmasına sebep olacaktır (Baş, 2012).

Eğitim alanında uygulanan ya da uygulanacak olan yeniliklerin okullarda yerleşmesini sağlayacak olan birey okul yöneticisidir. Bu yeniliklerin başında da teknoloji gelmektedir. Hızla değişen çevre okul yöneticilerinin keşfedici, değerlendiren, yeni teknoloji çeşitlerini zorlayan bir teknoloji lideri olmasını gerektirmektedir (Creighton, 2003). Değişim her sektör için kaçınılmaz bir olgudur ve değişimden etkilenmeyen bir birim yoktur. Bu anlamda liderler kurumlarda değişime öncü olacak kişilerdir. Liderler çeşitli araçlar ve yöntemlerden yararlanarak örgütün yapısını ve işlevini değiştirebilir. Lider değişime ayak uydurarak, çalışanları ile motivasyonu sağlayarak örgütsel değişimi gerçekleştirir (Tunçer, 2011). Buna bağlı olarak teknoloji lideri olan bir okul yöneticisi eğitim kurumu için teknolojik gelişmeleri yakından takip etmeli, gerekli donanımları sağlayıp, eğitmenlere de gerekli teknolojik alt yapıyı kazandırabilmelidir. 
Okul yöneticilerin teknoloji liderliği vasıflarına sahip olup olmadıklarının bilinmesi, bu liderlik türü aracılığıyla öğretme öğrenme süreçlerinde teknolojinin kullanımının sağlanması ve çağın gerektirdiği teknolojik gelişmelerin okuldaki tüm süreçlere uyarlanmasına öncülük edilmesi açısından gerekli ve önemlidir. Okul yöneticilerinin teknoloji liderliği rollerini sergileme durumlarının belirlenmesi, okul yöneticilerinin teknoloji liderliği boyutundaki öz değerlendirmeleri; somut gözlem ölçütlere dayalı olarak araştırmacılar/uzmanlar tarafindan değerlendirilmeleri veya öğretmen, öğrenci veli gibi çeşitli paydaşlar tarafından değerlendirmeleri yoluyla olabilir. Okul yöneticilerinin teknoloji liderliği rollerini değerlendirme açısından en önemli değerlendirme kaynağının yöneticiyle yakın ilişki içinde olmasından, yöneticinin uygulamalarından etkilenmesinden ve öğretme öğrenme süreçlerinde teknolojinin bu süreçlere uyarlanmasında ön planda olmasından dolayı öğretmenlerdir. Bu doğrultuda araştırmanın temel problemi öğretmenlerin okul yöneticilerinin teknoloji liderliği rolleri hakkındaki görüşlerinin belirlenmesidir. Okul yöneticilerinin teknoloji liderliği rollerinin öğretmen görüşleri doğrultusunda değerlendirilmesi genel amaciyla, öğretmenlerin yöneticilerinin teknoloji liderliği rollerinin seviyesine ilişkin görüşlerinin öğretmenlerin cinsiyetlerine, branşlarına, çalıştıkları okul türüne, mesleki kıdemine, eğitim teknolojileri ile ilgili eğitim alıp almama durumlarına, okuldaki teknolojik imkânları yeterli bulma düzeylerine, lisansüstü eğitim alma durumlarına göre istatiksel olarak farklılaşıp farklılaşmadığına ilişkin durumları incelenmiştir.

\section{Yöntem}

Bu bölümde, araştırmanın modeli ve evreni betimlendikten sonra, veri toplama araçları, verilerin çözümlenmesi üzerinde durulmuştur.

\section{Araştırma Modeli}

Bu araştırma 2016-2017 eğitim-öğretim y1lında Van İli Tuşba, İpekyolu, Erciş ve Edremit ilçelerindeki resmi ilköğretim ve ortaöğretim kurumlarında görev yapmakta olan öğretmenlerin, okul yöneticilerinin teknolojik liderlik becerilerini değerlendirilmesi amacına yönelik karşılaştırma türü genel tarama modelli bir araştırmadır. Karşılaştırma tarama modellerinde sınanmak istenen değişkene göre gruplar oluşturulur ve diğer değiş̧kene göre aralarında bir farklılaşma olup olmadığ incelenir (Karasar, 1999). Bu araştırmada resmi ilköğretim ve ortaöğretim kurumlarında görev yapmakta olan öğretmenlerin, okul yöneticilerinin teknolojik liderlik becerilerine yönelik değerlendirmelerinin çeşitli değişkenler 
açısından farklılaşma durumları incelendiğinden dolayı araştırma sözü edilen model kapsamındadır.

\section{Evren ve Örneklem}

Araştırmanın evrenini 2016-2017 eğitim-öğretim yılında Van ilindeki bulunan 1184 tane ilköğretim kurumu ve 61 tane ortaöğretim kurumunda çalışan 13883 öğretmen oluşturmaktadır. Araştırmanın örneklemini ise; nüfus bakımından en yoğun olan Tuşba, İpekyolu, Erciş ve Edremit ilçelerinde ulaşımın kolaylığı dikkate alınarak belirlenen 16 ilköğretim kurumu ve 21 ortaöğretim kurumunda çalışan öğretmenler arasından seçilen 452 öğretmen oluşturmaktadır. Örneklemin seçilmesinde uygun örnekleme kullanılmıştır.

Örnekleme giren öğretmenlerin belli başlı demografik özelliklerine ait dağılımlar tablo 1 'de verilmiştir.

Tablo 1.

Örnekleme Giren Öğretmenlerin Demografik Değişkenleri İçin Frekans ve Yüzde Değerleri

\begin{tabular}{llcc}
\hline & & $f$ & $\%$ \\
\hline \multirow{2}{*}{ Cinsiyet } & Erkek & 212 & 46,9 \\
& Kadın & 240 & 53,1 \\
\hline \multirow{4}{*}{ Okul türü } & İlkokul & 72 & 15,9 \\
& Ortaokul & 122 & 27,0 \\
& İmam Hatip Ortaokulu & 14 & 3,1 \\
& Fen Lisesi & 35 & 7,7 \\
& Anadolu Lisesi & 95 & 21,0 \\
& İmam Hatip Lisesi & 46 & 9,5 \\
& Mesleki ve Teknik Anadolu & 71 & 15,7 \\
\hline \multirow{4}{*}{ Branş } & Lisesi & 62 & 13,7 \\
& Sinı Öğretmeni & 106 & 23,5 \\
& Fen Alanları & 209 & 46,2 \\
& Sosyal Alanlar & 36 & 8,0 \\
& Yetenek Alanları & 39 & 8,6 \\
\hline \multirow{4}{*}{ Mesleki Kıdem } & Diğer & 218 & 48,2 \\
& 1-5 yll & 85 & 18,8 \\
& 6-10 y1l & 64 & 14,2 \\
& $11-15$ yıl & 85 & 18,8 \\
\hline
\end{tabular}

\section{Veri Toplama Araçları}

Araştırmada öğretmenlerin yöneticilerinin teknoloji liderliği rollerine ilişkin görüşlerini belirlemek üzere Sincar (2009) tarafından geliştirilen “Okul Yöneticisinin 
Teknoloji Liderliği Rolleri Ölçeği” veri toplama aracı olarak kullanılmıştır. Geçerlik analizleri faktör analiz yapılarak gerçekleştirilen çalışmada ölçek; "İnsan Merkezlilik” alt boyutu 11 madde, "Vizyon" alt boyutu 7 madde, "Iletişim ve Işsbirliği " alt boyutu 6 madde ve "Destek" alt boyutu 5 madde olacak şekilde toplamda dört alt boyut ve 29 maddeden oluşmaktadır. Ölçek 5'li likert tipi olup, "Hiçbir Zaman”(1), “Ara Sıra”(2), “Bazen”(3), “Sik Sik”(4), "Her Zaman"(5) şeklinde puan değerlerine sahip seçeneklerden oluşmaktadır. Teknoloji liderliği ölçeği puanlama alt ve üst sınırları (1) Hiç Katılmıyorum "1,00-1,79”; (2) Katılmıyorum "1,802,59"; (3) K1smen Kat1lyyorum "2,60-3,39”; (4) Kat1liyorum “3,40-4,19”; (5) Tamamen Katıl1yorum “4,20-5,00” olarak belirlenmiştir.

Ölçeğin güvenilirliği kapsamında iç tutarlılık katsayıları hesaplanmıştır. Ölçeğin orijinalinden ve mevcut araştırma verilerinden elde edilen cronbach alfa iç tutarlılık katsayıları Tablo 2'de verilmiştir.

Tablo 2.

Ölçeğin orijinali ve mevcut araştırma verilerine dayalı iç tutarlılık katsayıları

\begin{tabular}{lll}
\hline $\begin{array}{l}\text { Okul Yöneticilerinin Teknoloji Liderliği } \\
\text { Davranışları }\end{array}$ & Sincar (2009) & Mevcut araştırma \\
\hline İnsan Merkezlilik & .94 & .94 \\
\hline Vizyon & .92 & .96 \\
\hline İletişim ve İşbirliği & .91 & .91 \\
\hline e-destek & .91 & .95 \\
\hline Teknoloji Liderliği (Toplam) & .97 & .98 \\
\hline
\end{tabular}

Ölçeğin orijinalinden ve mevcut araştırmadan elde edilen cronbach alfa iç tutarlılık katsayılarının yüksek ve birbirleriyle tutarlı oldukları anlaşılmaktadır. Hatta mevcut araştırmadan elde edilen değerlerin daha yüksek olduğu boyutlar da bulunmaktadır. Elde edilen sonuçlar ölçeğin verilerinin elde edildiği grup açısından da güvenilir olduğunu ortaya koymaktadır.

\section{Verilerin Toplanması}

Bu çalışma 2016-2017 eğitim-öğretim y1lında Van İli’nde “Okul Yöneticisinin Teknoloji Liderliği Rolleri” ölçeği kullanılarak Edremit, Erciş, Tuşba ve İpekyolu ilçelerindeki ilköğretim ve ortaöğretim kurumlarında gerçekleşmiştir. Öğretmenlere çoğunlukla gün içerisinde ulaşılmış, dersi olmayan öğretmenlere ise bir sonraki gün anket uygulanmıştır. Uygulama sırasında öğretmenlerde gönüllülük esas alınarak, anketi doldurmak istemeyen 
öğretmenlere uygulama yapılmamıştır. Öğretmenlerin anketi doldurma süreleri 5-8 dakika sürmüştür.

\section{Verilerin Analizi}

Araştırmada öğretmenlerin kimlik bilgilerine yönelik olarak frekans ve yüzde hesaplamaları yapılmıştır. Araştırmanın amaçları doğrultusunda öğretmenlerin değişen niteliklere göre ölçekten almış oldukları puan değerleri hesaplanmış ve yorumlanmıştır. $\mathrm{Bu}$ sebeple burada yapılan varyans analizlerinde yer alan seçeneklere düşen değerlerin 30'dan aşağıya olduğu durumlarda parametrik olmayan testler tercih edilmiştir. Diğer durumlarda analizler parametrik teknikler olarak uygulanmıştır. $\mathrm{Bu}$ doğrultuda parametrik testler bağlamında bağımsız gruplar t-testi ve tek yönlü varyans analizi; parametrik olmayan testler bağlamında ise Mann Whitney U ve Kruskal Wallis analizleri kullanılmıştır.

\section{Bulgular ve Yorumlar}

Öğretmenlerin, okul yöneticilerinin teknoloji liderliği rollerine yönelik görüşlerinin seviyesine yönelik bulgular Tablo 3’te verilmiştir.

Tablo 3.

Öğretmenlerin Okul Yöneticilerinin Teknoloji Liderliği Rollerine Yönelik Görüşlerine İlişkin Betimsel Analizler

\begin{tabular}{llllll}
\hline $\begin{array}{l}\text { Okul Yöneticilerinin } \\
\text { Teknoloji Liderliği } \\
\text { Davranışları }\end{array}$ & $\mathrm{n}$ & En az & En çok & $\bar{x}$ & ss \\
\hline İnsan Merkezlilik & 452 & 1 & 5 & 3,25 &, 98 \\
Vizyon & 452 & 1 & 5 & 3,22 & 1,11 \\
İletişim ve İşbirliği & 452 & 1 & 5 & 3,14 & 1,04 \\
Destek & 452 & 1 & 5 & 3,37 & 1,11 \\
\hline Teknoloji Liderliği (Toplam) & 452 & 1 & 5 & 3,24 &, 99 \\
\hline
\end{tabular}

Tablo 3 incelendiğinde okul yöneticilerinin öğretmen görüşleri doğrultusunda teknoloji liderliği rollerine ait aritmetik ortalamaların insan merkezlilik boyutunda $\bar{x}=3,25$, vizyon boyutunda $\bar{x}=3,22$, iletişim ve işbirliği boyutunda $\bar{x}=3,14$, destek boyutunda $\bar{x}=3,37$ ve ölçeğin toplamında ise $\bar{x}=3,24$ olduğu görülmektedir. Okul yöneticilerinin teknoloji liderliği davranışlarını genelde ve tüm boyutlarda 5 'li dereceli ölçekte 3 seviyesine "kısmen katılıyorum" aralığına denk gelecek biçimde sergiledikleri anlaşılmaktadır. Elde edilen 
bulgulardan hareketle öğretmenlerin yöneticilerinin teknoloji liderliği rollerini orta seviyede sergilediklerini düşündükleri ifade edilebilir.

Tablo 4.

Okul Yöneticilerinin Teknoloji Liderliği Rollerine İlişkin Öğretmen Görüşlerinin "Öğretmenlerin Cinsiyetlerine" Göre Farklılaşma Durumuna Yönelik Bağımsız Grup t-Testi Analizi

\begin{tabular}{llcccccc}
\hline & Cinsiyet & $\mathrm{n}$ & $\bar{x}$ & $\mathrm{Ss}$ & $\mathrm{t}$ & $\mathrm{Sd}$ & $\mathrm{p}$ \\
\hline Teknoloji liderliği & Erkek & 212 & 3,27 & 1,03 & \multirow{2}{*}{0,55} & \multirow{2}{*}{450} & \multirow{2}{*}{5866} \\
(Toplam) & Kadın & 240 & 3,21 & 0,94 & & & \\
\hline
\end{tabular}

Tablo 4 incelendiğinde okul yöneticilerinin teknoloji liderliği rollerine yönelik genel görüşlerinin aritmetik ortalamasının erkek öğretmenlerde $\bar{x}=3,27$; kadın öğretmenlerde ise $\bar{x}$ $=3,21$ olduğu görülmektedir. Bu aritmetik ortalamalara uygulanan bağımsız grup t testi anlamlı bir fark ortaya koymamıştır $\left(\mathrm{t}_{(450)}=0,55, \mathrm{p}>0,05\right)$. Elde edilen bulgulardan hareketle kadın ve erkek öğretmenlerin okul yöneticilerinin teknoloji liderliği rollerine yönelik genel görüşlerinin farklılaşmadığı anlaşılmaktadır. Öğretmenlerin yöneticilerinin teknoloji liderliği rollerine ilişkin görüşleri öğretmenlerin cinsiyetlerine göre insan merkezlilik, vizyon, iletişim ve işbirliği ve destek boyutlarında değerlendirildiğinde de farklılaşma görülmemiştir.

Tablo 5 .

Okul Yöneticilerinin Teknoloji Liderliği Rollerine İlişkin Öğretmen Görüşlerinin “Öğretmenlerin Branşlarına” Göre Farklılaşma Durumuna Yönelik Tek Yönlü Varyans Analizi $f, \overline{\mathrm{x}}$ ve $s s$ Değerleri ANOVA Sonuçları

\begin{tabular}{lllllllllll}
\hline Puan & Grup & $\mathrm{n}$ & $\overline{\mathrm{x}}$ & ss & Var. K. & $K T$ & $S d$ & $K O$ & $F$ & $p$ \\
\hline \multirow{3}{*}{ Teknoloji } & Sinıf Öğr. & 62 & 3,45 & 0,78 & G.Aras1 & 6,84 & 4 & 1,709 & & \\
Liderliği & Fen A. & 106 & 3,32 & 1,01 & G.İçi & 435,11 & 447 &, 973 & & \\
(Toplam) & Sosyal A. & 209 & 3,15 & 1,03 & Toplam & 441,94 & 451 & & 1,76 &, 137 \\
& Yetenek A. & 36 & 3,06 & 0,98 & & & & & & \\
& Diğer & 39 & 3,37 & 0,98 & & & & & & \\
& Toplam & 452 & 3,24 & 0,99 & & & & & & \\
\hline
\end{tabular}

Tablo 5'te görüldüğü üzere örneklem grubunu oluşturan öğretmenlerin yöneticilerin teknoloji liderliği rolleri ölçeği puanlarının branş değişkenine göre anlamlı bir farklılık gösterip göstermediğini belirlemek amacıyla yapılan tek yönlü varyans analizi sonucunda grupların aritmetik ortalamaları arasındaki farklılık anlamlı bulunmamıştır $\left(F_{(4-447)}=1,76 ; p>0,05\right)$. Elde edilen sonuçtan hareketle, okul yöneticilerinin teknoloji liderliği rollerinin öğretmen görüşleri doğrultusunda branşlara göre farklılaşmadığı tespit edilmiştir. Alt boyutlarda da okul yöneticilerinin teknoloji liderliği rollerinin öğretmen görüşleri doğrultusunda branşlara göre farklılaşmadığ sonucuna ulaşılmıştır. 
Tablo 6.

Okul Yöneticilerinin Teknoloji Liderliği Rollerine İlişkin Öğretmen Görüşlerinin "Öğretmenlerin Çalıştıkları Okul Türüne” Göre Farklılaşma Durumuna Yönelik Kruskal Wallis Analizi

\begin{tabular}{lllllll}
\hline Puan & Gruplar & $\mathrm{n}$ & $\bar{x}_{\text {sira }}$ & $x^{2}$ & sd & $\mathrm{p}$ \\
\hline & İlkokul & 72 & 247,68 & & & \\
& Ortaokul & 122 & 178,13 & & & \\
Teknoloji & İmam Hatip Ortaokulu & 14 & 302,54 & & & \\
Liderliği & Fen Lisesi & 35 & 303,04 & & & \\
(Toplam) & Anadolu Lisesi & 95 & 243,06 & 37,52 & 6 &, 000 \\
& İmam Hatip Lisesi & 43 & 224,26 & & & \\
& Mesleki ve Teknik Anadolu & 71 & 214,62 & & & \\
& Lisesi & & & & & \\
\cline { 2 - 7 } & Toplam & & & & & \\
\hline
\end{tabular}

Tablo 6'da görüldüğü üzere örneklem grubu oluşturan öğretmenlerin yöneticilerin teknoloji liderliği rolleri ölçeği sıralama ortalamalarının öğretmenlerin çalıştıkları okul türü değişkenine göre farklılaşıp farklılaşmadığını belirlemek amacıyla yapılan Kruskal Wallis analizi sonucunda grupların sıralama ortalamaları arasındaki farklılık anlamlı bulunmuştur $\left(\mathrm{x}^{2}=37,52 ; \mathrm{p}<, 01\right)$. Hangi iki grup arasında farklılaşma olduğu belirlemek için Mann Whitney $\mathrm{U}$ analizi yapılmıştır.

Tablo 7.

Okul Yöneticilerinin Teknoloji Liderliği Davranışlarına Teknoloji Liderliği Rollerine İlişkin Öğretmen Görüşlerinin “Öğretmenlerin Çalıştıkları Okul Türüne” Göre Farklılaşma Durumuna Yönelik Mann Whitney U Analizi

\begin{tabular}{|c|c|c|c|c|c|c|c|}
\hline Gruplar & İlkokul & Ortaokul & $\begin{array}{l}\text { İmam } \\
\text { Hatip } \\
\text { Ortaokulu }\end{array}$ & $\begin{array}{l}\text { Fen } \\
\text { Lisesi }\end{array}$ & $\begin{array}{l}\text { Anadolu } \\
\text { Lisesi }\end{array}$ & $\begin{array}{l}\text { İmam } \\
\text { Hatip } \\
\text { Lisesi }\end{array}$ & $\begin{array}{l}\text { Mesleki ve } \\
\text { Teknik } \\
\text { Anadolu } \\
\text { Lisesi }\end{array}$ \\
\hline İO & $\begin{array}{l}\bar{x}_{\text {slra }}= \\
247,68\end{array}$ & $\mathrm{p}<, 01$ & $\mathrm{p}<, 05$ & $\mathrm{p}<, 01$ & - & - & - \\
\hline $\mathrm{OO}$ & & $\begin{array}{l}\bar{x}_{\text {sira }}= \\
178,13\end{array}$ & $\mathrm{p}<, 01$ & $\mathrm{p}<, 01$ & $\mathrm{p}<, 01$ & $\mathrm{p}<, 05$ & - \\
\hline İHOO & & & $\begin{array}{l}\bar{x}_{\text {sira }}= \\
302,54\end{array}$ & - & - & $\mathrm{p}<, 05$ & $\mathrm{p}<, 05$ \\
\hline FL & & & & $\begin{array}{l}\bar{x}_{\text {sira }}= \\
303,04\end{array}$ & $\mathrm{p}<, 05$ & $\mathrm{p}<, 01$ & $\mathrm{p}<, 01$ \\
\hline $\mathrm{AL}$ & & & & & $\begin{array}{l}\bar{x}_{\text {sira }}= \\
243,06\end{array}$ & - & - \\
\hline İHL & & & & & & $\begin{array}{l}\bar{x}_{\text {sira }}= \\
224,26\end{array}$ & - \\
\hline MTAL & & & & & & & $\begin{array}{l}\bar{x}_{\text {sira }}= \\
214,62\end{array}$ \\
\hline
\end{tabular}


Tablo 7'de görüldüğü üzere örneklem grubunu oluşturan öğretmenlerin yöneticilerin teknoloji liderliği rollerine ilişkin puanlarının okul türü değişkenine göre anlamlı bir farklılık gösterip göstermediğini belirlemek amacıyla yapılan Mann Whitney U sonucunda ilkokullarda görev yapan öğretmenlerin yöneticilerinin teknoloji liderliği rollerine yönelik görüşlerinin ortaokuldaki öğretmenlerin görüşlerine göre daha olumlu/yüksek olduğu anlaş1lmaktadır. Diğer yandan imam hatip ortaokullarındaki öğretmenlerin yöneticilerinin teknoloji liderliği rollerine ilişkin görüşlerinin de ortaokul ve ilkokul öğretmenlerini görüşlerinden anlamlı seviyede olumlu olduğu görülmektedir. Tüm okul türlerine ve kademelerine genel olarak bakıldığında ortaokul öğretmenlerinin ve mesleki teknik Anadolu lisesi öğretmenlerinin yöneticilerinin teknoloji liderliği rollerine yönelik görüşlerinin farkl1laşmadığı ve bu iki okul kademesindeki öğretmenlerin tüm gruplar içindeki görüşlerinin en düşük seviyede olduğu anlaşılmaktadır.

Tablo 8.

Okul Yöneticilerinin Teknoloji Liderliği Rollerine İlişkin Öğretmen Görüşlerinin “Öğretmenlerin Mesleki Kıdemine” Göre Farklılaşma Durumuna Yönelik Tek Yönlü Varyans Analizi

\begin{tabular}{|c|c|c|c|c|c|c|c|c|c|c|}
\hline \multicolumn{5}{|c|}{$\overline{f, \overline{\mathrm{x}} \text { ve } s s \text { Değerleri }}$} & \multicolumn{6}{|c|}{ ANOVA Sonuçları } \\
\hline Puan & Grup & $\mathrm{n}$ & $\overline{\mathrm{x}}$ & $s S$ & Var. K. & $K T$ & $S d$ & $K O$ & $F$ & $p$ \\
\hline \multirow{6}{*}{$\begin{array}{l}\text { Teknoloji } \\
\text { Liderliği } \\
\text { (Toplam) }\end{array}$} & $1-5$ y1l & 218 & 3,25 & ,98 & G.Aras1 & 1,88 & 4 & 47 & \multirow{5}{*}{\multicolumn{2}{|c|}{,48, 752 }} \\
\hline & $6-10 \mathrm{y} 1 \mathrm{l}$ & 85 & 3,15 & ,98 & G.İçi & 440,06 & 447 & ,98 & & \\
\hline & $11-15 \mathrm{y} 1 \mathrm{l}$ & 64 & 3,19 & ,97 & Toplam & 441,94 & 451 & & & \\
\hline & $16-20 \mathrm{y} 1 \mathrm{l}$ & 50 & 3,30 & 1,04 & & & & & & \\
\hline & 21 y1l ve üzeri & 35 & 3,40 & 1,05 & & & & & & \\
\hline & Toplam & 452 & 3,24 & 99 & & & & & & \\
\hline
\end{tabular}

Tablo 8'de görüldüğü üzere öğretmenlerin yöneticilerin teknoloji liderliği rolleri ölçeği puanlarının mesleki kıdem değişkenine göre anlamlı bir farklılık gösterip göstermediğini belirlemek amacıyla yapılan tek yönlü varyans analizi sonucunda grupların aritmetik ortalamaları arasındaki farklılık anlamlı bulunmamıştır $\left(\mathrm{F}_{(4-447)}=0,48 ; \mathrm{p}>, 05\right)$. Elde edilen sonuçtan hareketle, okul yöneticilerinin teknoloji liderliği rollerinin öğretmen görüşleri doğrultusunda mesleki kıdeme göre farklılaşmadığı tespit edilmiştir.Alt boyutlarda da okul yöneticilerinin teknoloji liderliği rollerinin öğretmen görüşleri doğrultusunda öğretmenlerin mesleki kıdemlerine göre farklılaşmadığı sonucuna ulaşılmıştır. 
Tablo 9.

Okul Yöneticilerinin Teknoloji Liderliği Rollerine İlişkin Öğretmen Görüşlerinin “Öğretmenlerin Eğitim Teknolojileri İle İlgili Eğitim Alıp-Almadıklarına" Göre Farklılaşma Durumuna Yönelik Bağımsız Grup t-Testi Analizi

\begin{tabular}{llllllll}
\hline & $\begin{array}{l}\text { Eğitim Alma } \\
\text { Durumu }\end{array}$ & $\mathrm{n}$ & $\overline{\mathrm{x}}$ & Ss & $\mathrm{t}$ & $\mathrm{Sd}$ & $\mathrm{p}$ \\
\hline $\begin{array}{l}\text { Teknoloji Liderliği } \\
\text { (Toplam) }\end{array}$ & $\begin{array}{l}\text { Aldı } 1 \\
\text { Almadı }\end{array}$ & 296 & 3,24 & 1,01 & 0,55 & 450 &, 967 \\
\hline
\end{tabular}

Tablo 9 incelendiğinde öğretmenlerin okul yöneticilerinin teknoloji liderliği rollerine yönelik genel görüşlerinin aritmetik ortalamasının eğitim teknolojileri ile ilgili eğitim alan öğretmenlerde ve eğitim teknolojileri ile ilgili eğitim almayan öğretmenlerde de $\bar{x}=3,24$ olduğu görülmektedir. $\mathrm{Bu}$ aritmetik ortalamalara uygulanan bağımsız grup $\mathrm{t}$ testi anlamlı bir fark ortaya koymamıştır $\left(\mathrm{t}_{(450)}=0,55, \mathrm{p}>0,05\right)$. Elde edilen bulgulardan hareketle eğitim teknolojileri ile ilgili eğitim alan ve almayan öğretmenlerin okul yöneticilerinin teknoloji liderliği rollerine yönelik genel görüşlerinin farklılaşmadığı anlaşılmaktadır. Genel duruma paralel olarak alt boyutlarda da öğretmenlerin okul yöneticilerinin teknoloji liderliği rollerine ilişkin görüşleri öğretmenlerin eğitim teknolojileri ile ilgili eğitim alıp-almadıklarına göre farklılaşmamıştır.

Tablo 10.

Okul Yöneticilerinin Teknoloji Liderliği Rollerine İlişkin Öğretmen Görüşleri “Öğretmenlerin Okuldaki Teknolojik İmkânları Yeterli Bulma Düzeylerine” Göre Farklılaşma Durumuna Yönelik Kruskal Wallis Analizi

\begin{tabular}{lllllll}
\hline Puan & Gruplar & $\mathrm{n}$ & $\bar{x}_{\text {sira }}$ & $x^{2}$ & sd & $\mathrm{p}$ \\
\hline \multirow{3}{*}{ Teknoloji } & Hiç yeterli bulmuyor & 69 & 155,50 & & & \\
Liderliği & Az yeterli buluyor & 184 & 219,45 & & & \multirow{2}{*}{000} \\
(Toplam) & Oldukça yeterli buluyor & 183 & 251,16 & & 3 & \\
\cline { 2 - 7 } & Toplam yeterli buluyor & 16 & 331,75 & & & \\
\hline
\end{tabular}

Tablo 10'da görüldüğü üzere öğretmenlerin yöneticilerin teknoloji liderliği rolleri ölçeği sıralama ortalamalarının öğretmenlerin okuldaki teknolojik imkânları yeterli bulma düzeylerine göre farklılaşıp farklılaşmadığını belirlemek amacıyla yapılan Kruskal Wallis analizi sonucunda grupların sıralama ortalamaları arasındaki farklılık anlamlı bulunmuştur $\left(x^{2}=37,84 ; p<, 001\right)$. Hangi gruplar arasında farklılık olduğunu anlamak için Mann Whitney U analizi uygulanmıştır. 
Tablo 11.

Öğretmenlerin Yöneticilerin Teknoloji Liderliği Rolleri Ölçeği Puanlarının "Öğretmenlerin Okuldaki Teknolojik İmkânları Yeterli Bulma Düzeylerine" Göre Hangi Gruplar Arasında Farklılaştı̆̆ını Belirlemek Üzere Yapılan Mann Whitney U Testi Sonuçları

\begin{tabular}{lcccc}
\hline Gruplar & $\begin{array}{c}\text { Hiç yeterli } \\
\text { bulmuyor }\end{array}$ & $\begin{array}{c}\text { Az yeterli } \\
\text { buluyor }\end{array}$ & $\begin{array}{c}\text { Oldukça yeterli } \\
\text { buluyor }\end{array}$ & $\begin{array}{c}\text { Cok yeterli } \\
\text { buluyor }\end{array}$ \\
\hline $\begin{array}{l}\text { Hiç yeterli bulmuyor } \\
\text { Az yeterli buluyor }\end{array}$ & $\bar{x}_{\text {sıra }}=155,50$ & $\mathrm{p}<, 01$ & $\mathrm{p}<, 01$ & $\mathrm{p}<, 01$ \\
Oldukça yeterli buluyor & & $\bar{x}_{\text {sira }}=219,45$ & $\mathrm{p}<, 05$ & $\mathrm{p}<, 01$ \\
Çok yeterli buluyor & & & $\bar{x}_{\text {sira }}=251,16$ & $\mathrm{p}<, 05$ \\
& & & $\bar{x}_{\text {sira }}=331,75$ \\
\hline
\end{tabular}

Tablo 11'de öğretmenlerin yöneticilerin teknoloji liderliği rolleri ölçeği puanlarının öğretmenlerin okuldaki teknolojik imkânları yeterli bulma düzeylerine göre hangi gruplar arasında farklılaştığını belirlemek üzere yapılan Mann Whitney U analizi yapılmıştır. Elde edilen bulgulara göre okuldaki teknolojik imkânları çok yeterli bulan öğretmenlerin yöneticilerinin teknolojik liderliği rollerine yönelik görüşleri okuldaki teknolojik imkânları hiç yeterli bulmayan, az yeterli bulan ve oldukça yerli bulan öğretmenlerinkine göre daha olumlu ve yüksek düzeydedir.

Bunun yanında öğretmenlerin okul yöneticilerinin teknoloji liderliği rollerine ilişkin görüşleri öğretmenlerin okuldaki teknolojik imkânları yeterli bulma düzeylerine göre alt boyutlarda da farklılaşmaktadır.

Tablo 12.

Okul Yöneticilerinin Teknoloji Liderliği Rollerine İlişkin Öğretmen Görüşlerinin "Öğretmenlerin Lisansüstü Eğitim Alma Durumlarına" Göre Farklılaşma Durumuna Yönelik Bağımsız Grup t-Testi Analizi

\begin{tabular}{llcccccc}
\hline & Lisansüstü Eğitim & $\mathrm{n}$ & $\overline{\mathrm{x}}$ & $\mathrm{Ss}$ & $\mathrm{t}$ & $\mathrm{Sd}$ & $\mathrm{p}$ \\
\hline Alma Durumu & & 98 & 3,26 & 1,04 & \multirow{2}{*}{, 151} & \multirow{2}{*}{450} & \multirow{2}{*}{, 880} \\
(Toknoloji Liderliği & Aldı & Almadı & 354 & 3,24 &, 98 & &
\end{tabular}

Tablo 12 incelendiğinde öğretmenlerin okul yöneticilerinin teknoloji liderliği rollerine yönelik genel görüşlerinin aritmetik ortalamasının lisansüstü eğitim alanlar öğretmenlerde $\bar{x}$ $=3,26$; lisansüstü eğitim almayanlarda ise $\bar{x}=3,24$ olduğu görülmektedir. $\mathrm{Bu}$ aritmetik ortalamalara uygulanan bağımsız grup t testi anlamlı bir fark ortaya koymamıştır $\left(\mathrm{t}_{(450)}=0,151\right.$, p >0,05). Elde edilen bulgulardan hareketle lisansüstü eğitim alan ve lisansüstü eğitim almayan öğretmenlerin okul yöneticilerinin teknoloji liderliği rollerine yönelik genel görüşlerinin farklılaşmadığı anlaşılmaktadır. 


\section{Sonuç ve Tartışma}

Araştırmanın amaçları doğrultusunda ulaşılan sonuçlar bu kısımda verilmiş ve tartışılmıştır.

Öğretmenler yöneticilerinin teknoloji liderliği rollerini orta düzeyde sergilediklerini düşünmektedirler.

Ölçeğin alt boyutlardan elde edilen bulgular sonucunda, öğretmenler yöneticilerinin teknoloji liderliğine ilişkin rollerini, vizyon, iletişim ve işbirliği, insan merkezlilik ve destek boyutunda “orta düzeyde"sergiledikleri sonucuna ulaşılmıştır.

Elde edilen sonuçlar doğrultusunda genel bir değerlendirme yapıldığında öğretmenlerin yöneticilerinin teknoloji liderliği rollerine ilişkin görüşleri orta seviyededir. Sincar’a (2011) göre; öğretmenlerin yöneticilerin teknoloji liderliği rollerine ilişkin görüşleri insan merkezlilik, vizyon, iletişim ve işbirliği boyutunda kısmen; destek boyutunda ise yeterince olduğu sonucuna ulaşılmıştır. Öztaş (2013); öğretmenlerin yöneticilerinin teknoloji liderliği rollerine ilişkin genel değerlendirmelerini Sincar, M. (2009) tarafindan geliştirilen "İlköğretim Okulu Yöneticilerinin Teknoloji Liderliği Ölçeği”ni uygulayarak kısmen olarak; Hayytov (2013) “Okul Yöneticileri Teknoloji Liderliği Yeterlilik Algıları Ölçeği”ni ve Ölçek (2014) “İlköğretim Okulu Yöneticilerinin Teknoloji Liderliği Rolleri Ölçeği”ni uygulayarak genel algıyı olumlu yönde; Irmak (2015) ve Baş da (2012) “Teknoloji Liderliği Rolleri Ölçeği”ni uygulayarak genel algıyı yüksek düzeyde bulmuştur. Engür (2014) “Okul Müdürlerinin Teknoloji Liderliği Ölçeği’"ni uygulayarak yöneticilerin teknoloji liderliği düzeylerini 3 boyutta ele aldığı çalışmasında 'verimlilik ve profesyonel' boyutunda yükssek 'ölçme ve değerlendirme, sosyal, hukuki ve etik konular' ve 'liderlik ve vizyon, öğrenme ve öğretme, destek, yönetim ve işlemler' boyutlarında da orta düzeyde olarak belirlemiştir.

Öğretmenlerin yöneticilerin teknoloji liderliği rollerine ilişkin görüşlerinin öğretmenlerin cinsiyetlerine göre farklılaşıp farklılaşmadığına yönelik bulgular toplamda ve alt boyutlarda ayrı ayrı değerlendirildiğinde anlamlı bir farklılık belirlenmemiştir. Bu durumda öğretmenlerin yöneticilerinin teknoloji liderliği rollerine ilişkin görüşleri öğretmenlerin cinsiyetine göre farklılaşmamaktadır. Benzer olarak; Uysal Balaban (2012), Baş (2012), Sincar ve Aslan (2011), Öztaş (2013), Irmak (2015), Hayytov (2013), Ölçek (2014) ve Engür (2014); araştırmalarında, öğretmenlerin yöneticilerinin teknoloji liderliği rollerine ilişkin görüşlerinin öğretmenlerin cinsiyetlerine göre farklılaşmadığı sonucuna ulaşmışlardır. 
Öğretmenlerin yöneticilerinin teknoloji liderliği rollerine ilişkin görüşlerinin branşlarına göre toplamda ve alt boyutlarda farklılaşmadığı anlaşılmaktadır. Sincar ve Aslan (2011), Irmak (2015), Uysal Balaban (2012) ve Engür'e (2014) göre branş değişkeni öğretmenlerin görüşlerinde fark oluşturmuş ve sınıf öğretmelerinin branş öğretmenlerine göre daha olumlu görüşlere sahip olduğu belirlenmiştir. Öztaş'ın (2013) çalışmasında ise; insan merkezlilik, vizyon ve destek boyutlarında sayısal alan ile teknik ve mesleki branşlarda farklılık bulunmuştur. Baş'a (2012) göre; insan merkezlilik boyutu dışında sınıf öğretmenleriyle branş öğretmenleri; sayısal branş öğretmenleriyle sözel branş öğretmenleri arasında, insan merkezlilik boyutunda ise diğer branş öğretmenleriyle sınıf öğretmenleri ve sözel branş öğretmenleri arasında anlamlı farklılığın olduğu görülmüştür. Ölçek’e (2014) göre ise; branş değişkeni yöneticilerin teknoloji liderliği düzeylerinde bir fark oluşturmamıştır.

Sincar (2011), Irmak (2015) , Uysal Balaban (2012) ve Engür (2014) sinıf öğretmenlerinin branş öğretmenlerine göre daha olumlu görüşlere sahip olmasını, sınıf öğretmenlerinin branş öğretmenlerine göre teknolojiyi eğitim ortamında daha az kullanmalarından kaynaklandığı biçiminde yorumlarlarken; mevcut araştırmada bir fark çıkmamıştır. Buna göre sınıf öğretmenlerinin teknolojiyi daha az kullanması yorumunun etraflıca ele alınması ve bu alanda yapılan araştırmaların arttırılmasını gerektirir.

Öğretmenlerin okul yöneticilerinin teknoloji liderliği rollerine ilişkin görüşlerinin okul türüne göre farklılaşmasına ilişkin bulgular yorumlandığında, ilkokulda görev yapan öğretmenlerin görüşlerinin ortaokulda görev yapan öğretmenlerin görüşlerinden daha olumlu olduğu sonucuna ulaşılmıştır. Mesleki ve teknik Anadolu lisesinde ve ortaokulda görev yapan öğretmenlerin görüşlerinin ise tüm gruplar içerisinde daha düşük seviyede olduğu belirlenmiştir. Bunun yanında fen liselerinde görev yapan öğretmenlerin yöneticilerinin teknoloji liderliğine yönelik görüşleri Anadolu, imam hatip ve mesleki ve teknik Anadolu liselerinde görev yapan öğretmenlerin görüşlerine göre daha yüksektir. Ortaokul ve mesleki ve teknik Anadolu liselerinde görev yapan öğretmenlerin ise yöneticilerinin teknoloji liderliği rollerine yönelik görüşleri farklılaşmamaktadır. Ortaokullarda görev yapan öğretmenlerin yöneticilerinin teknoloji liderliği rollerine ilişkin görüşleri diğer okul türlerine göre farklılaşmakla beraber daha olumsuzdur. Fen liselerinde görev yapan öğretmenlerin yöneticilerinin teknoloji liderliğine yönelik görüşleri imam hatip liselerinde ve ilkokullarda görev yapan öğretmenlere göre olumludur. Ortaokullarda görev yapan öğretmenlerin yöneticilerinin teknoloji liderliğine ilişkin görüşleri diğer okul türlerine göre farklılaşmakla 
beraber daha olumsuzdur. Fen liselerinde görev yapan öğretmenlerin yöneticilerinin teknoloji liderliği rollerine ilişkin görüşleri imam hatip liselerinde görev yapan öğretmenlere göre daha yüksektir. Diğer yandan ortaokul ve mesleki ve teknik Anadolu liselerinde görev yandan öğretmenlerin yöneticilerin teknoloji liderliğine ilişkin görüşleri farklılaşmamakla beraber daha olumsuz düzeydedir.

Genel olarak değerlendirildiğinde öğretmenlerin yöneticilerinin teknoloji liderliğine ilişkin görüşleri okul türüne göre farklılaşmaktadır. Engür'e (2014) göre de çalış1lan okul türü öğretmenlerin görüşlerinde anlamlı farklılıklar oluşturmuştur. Hayytov’un (2013) çalışmasına göre yöneticilerin teknoloji liderliği rollerine ilişkin görüşleri okul türüne göre farklılaşmamaktadır.

Okul türünün teknoloji liderliği rollerini etkilemesi, okulların teknolojik donanımlarının ve teknoloji kullanım alanlarının birbirinden farklı olmasına dayandırılabilir. Aynı zamanda farklı okul türlerindeki öğretmenlerin yöneticilerine yönelik teknoloji liderliği beklentilerinin farklı olmasından da kaynaklanabilir.

Öğretmenlerin mesleki kıdeme göre yöneticilerinin teknoloji liderliği rollerine ilişkin görüşlerinin farklılaşmasına ilişkin bulgular ele alındığında mesleki kıdeme göre öğretmenlerin görüşlerinin farklılaşmadığı belirlenmiştir Alt boyutlara bakıldığında da bu farklılığın olmadığı anlaşılmaktadır. Buna göre; mesleki kıdem öğretmenlerin yöneticilerin teknoloji liderliği rollerine ilişkin görüşlerinde etkili değildir. Irmak (2015), Uysal Balaban (2012) ve Ölçek (2014) çalışmalarına göre; öğretmenlerin yöneticilerin teknoloji liderliği rollerine ilişkin görüşleri mesleki kıdeme göre farklılaşmazken; Öztaş’ın (2013) yaptığı çalışmaya göre iletişim ve işbirliği boyutu dışındaki boyutlarda kıdeme göre farklılık anlamlı bulunmuştur. Baş’ın (2012) yaptığı araştırmada mesleki kıdeme göre tüm boyutlarda ve toplamda görüşlerin anlamlı bir fark oluşturduğu görülmüştür.

Öğretmenlerin görüşleri mesleki kıdeme göre bazı çalışmalarda fark yaratırken; bazı çalışmalar da ise fark yaratmamıştır. Bu durumun sebebi olarak, araştırma yapılan koşulların, örneklemin seçildiği alanların birbirinden farklı olması gösterilebilir

Öğretmenlerin teknoloji ile ilgili eğitim alıp-almama durumuna göre yöneticilerin teknoloji liderliği rollerine ilişkin görüşleri arasında anlamlı bir farklılık görülmemiştir. Alt boyutlarda da bu farklılığın olmadığı sonucuna ulaşılmıştır. Öğretmenlerin okul yöneticilerinin teknoloji liderliği rollerine ilişki görüşleri öğretmenlerin teknoloji ile ilgili eğitim alıp-almama 
durumuna göre farklılaşmaktadır. Benzer şekilde Irmak (2015) ve Hayytov (2013) öğretmenlerin teknoloji ile ilgili eğitim almalarının yöneticileri teknoloji liderliği rollerine ilişkin görüşlerinı etkilemediği sonucuna ulaşmıştır.

Öğretmenlerin teknoloji alanında eğitim alıp daha geniş bilgilere ulaşmaları onların yöneticilerini değerlendirmelerinde bir fark ortaya koymamıştır.

Öğretmenlerin yöneticilerinin teknoloji liderliği rollerine ilişkin görüşleri öğretmenlerin okuldaki teknolojik imkânları yeterli bulma düzeylerine göre farklılaşmaktadır. Genel değerlendirmeye bakıldığında okuldaki teknolojik imkânları çok yeterli bulan öğretmenlerin yöneticilerinin teknoloji liderliği rollerine ilişkin görüşleri okuldaki teknolojik imkânları hiç yeterli bulmayan, az yeterli bulan ve oldukça yeterli bulan öğretmenlerinkine göre daha yüksektir. Okuldaki teknolojik imkânları hiç yeterli bulmayan öğretmenlerin yöneticilerinin teknoloji liderliği rollerine ilişkin görüşleri; okuldaki teknolojik imkânları az yeterli bulan, oldukça yeterli bulan ve çok yeterli bulanlara göre daha düşüktür. Alt boyutların dördünde aynı sonuca ulaşıılmıştır

Okuldaki teknolojik imkânlar yeterli oldukça öğretmenlerin yöneticilerinin teknoloji liderliği rollerine ilişkin görüşleri daha olumlu ve yüksek düzeydedir. O halde okuldaki teknolojik donanımların eğitim şartlarına göre uygun hale getirilmesi yöneticilerin teknoloji liderliği rollerini yeteri düzeyde sergileyebilmelerine yardımcı olduğu ifade edilir.

Öğretmenlerin yöneticilerinin teknoloji liderliği rollerine ilişkin görüşleri öğretmenlerin lisansüstü eğitim alıp-almama durumlarına göre değerlendirildiğinde herhangi bir farklılığın olmadığı sonucuna ulaşılmıştır. Alt boyutlara göre bulgular incelendiğinde de herhangi bir farklılık tespit edilmiştir. Buna göre öğretmenlerin yöneticilerinin teknoloji liderliği rollerine ilişki görüşlerinin öğretmelerin lisansüstü eğitim alıp-almama durumuna göre farklılaşmadığı anlaşılmaktadır. Hayytov'a (2013) göre; ön lisans mezunu öğretmenlerin yöneticilerin teknoloji liderliği rollerine ilişkin görüşleri lisans ve lisansüstü eğitim alanlara göre daha düşüktür.

Genel olarak değerlendirildiğinde mevcut çalışmada ön lisans eğitimi alan öğretmen olmadığından Hayytov’un (2013) araştırmasıyla doğrudan bir karşılaştırma yapmak mümkün değildir. Ancak lisans ve lisansüstü bağlamında öğretmenlerin yöneticilerinin teknolojik liderlik rollerine ilişkin görüşlerinin farklılaşmamasını alınan programlarda teknoloji liderliğine yönelik özel bir uzmanlaşma olmamasına bağlayabiliriz 


\section{Öneriler}

Yapılan araştırma öncelik öğretmenlerin yöneticilerinin teknoloji liderliği rollerine üst düzeyde sahip olmadıklarını gösteriyor. Mevcut araştırmada da öğretmenler yöneticilerin teknoloji liderliği rollerine ilişkin görüşleri orta düzeydedir. Bu anlamda yöneticilerin teknoloji kullanımı ile ilgili deneyimlerinin arttırılması ve eğitim ortamı içerisinde bu deneyimlerini sergileyebilmeleri gerekir. Bunun için okulun internet sitesi yöneticiler tarafından aktif bir şekilde kullanılmalı, sosyal medya hesapları okulun vizyonları doğrultusunda veliler ile iletişim yolu olarak düzenlenebilmelidir.

Mevcut araştırmada okuldaki teknolojik imkânları çok yeterli bulan öğretmenlerin yöneticilerinin teknoloji liderliği rollerine ilişkin görüşleri genel olarak daha yüksek bulunmuştur. Okullardaki teknolojik imkanların geliştirilmesi okul yöneticilerinin teknoloji lideri olarak algılanması açısından önemli görülmektedir. İmkanların yeterli olmadığı okullarda öğretmenlerin okul yöneticilerini yeterli teknoloji liderliğine sahip olmamasından hareketle bu imkânlar geliştirilmelidir. Ancak sadece imkanların geliştirilmesi değil okul yöneticilerinin bu konuda eğitilmesi de önemlidir. Buradan yola çıkarak okul yöneticilerine eğitim alanında kullanılabilecek her türlü teknolojik yazılımlar ve araçlar tanıtılmalı, kullanımı hakkında bilgi verilmeli, eğitimler uygulamalı olarak verimli bir şekilde gerçekleşmelidir. Verilen eğitimin ardından okul yöneticilerinin kendi okullarındaki teknoloji kullanımı okuldaki teknolojik imkânlar göz önüne alınarak takibi sağlanmalıdır. MEB tarafından teknolojinin eğitimde kullanımı ile ilgili kitapçıklar hazırlanıp okul idarecilerine dağıtılmalıdır. Okul yöneticilerinin teknoloji kullanım takibi ilçe milli eğitimlerde yapılacak toplantılarda rapor halinde çalışmaları sergilemeleri istenmelidir. Bununla birlikte teknolojik imkânların öğretmenler tarafindan daha iyi olarak algılandığg okullarda yöneticilerin teknolojik liderlik rollerinin daha yüksek/olumlu değerlendirilmesinden hareketle okulların teknolojik imkânlarının geliştirilmesi gerekir.

Öğretmenlerin yöneticilerinin teknoloji liderliği rollerine ilişkin görüşleri teknoloji ile ilgili eğitim alma durumlarına göre farklılaşmamaktadır. Buna göre öğretmenlerin teknoloji ile ilgili aldıkları eğitimler yeterli olmadığı düşünülebilir. Öğretmenlerin de okul yöneticilerine teknoloji alanında yeterli destek sağlayabilmeleri için eğitim teknolojileri ile ilgili eğitim tüm öğretmenlere verimli bir şekilde ulaştırılmalıdır ve bu eğitimler bizzat eğitim ortamı içerisinde uygulamalı olarak yapılmalıdır. Eğitimde kullanılan e-programlar bu alanda uzman kişiler 
tarafından okullarda uygulamalı olarak gösterilmeli, öğretmenlerden de uygulamalı olarak geri dönüt alınmalıdır.

Okullardaki teknolojik imkânlar okul yöneticilerinin teknoloji lideri olarak rollerini sergileyebilmesine ve öğretmenler tarafından bu liderlik rollerinin olumlu değerlendirilmelerini sağlamaktadır. Bu sebeple öncelikle MEB tarafından okullara gerekli teknolojik araç-gereç ve yazılımların temin edilerek bunların güncel ve işler tutulabilmesi ilgili birimler tarafından sağlanmalıdır.

Bilişim ve teknoloji öğretmenlerinin aldıkları teknoloji ve teknolojinin eğitimde kullanılması formasyonundan hareketle sadece ve derinlemesine o alandaki öğretmenlerin yöneticilerin teknoloji liderliğine ilişkin rollerinin değerlendirilmesine yönelik araştırmalar planlanabilir.

\section{Makalenin Bilimdeki Konumu}

Eğitim Bilimleri/Eğitim Yönetimi ve Denetimi

\section{Makalenin Bilimdeki Özgünlüğü}

Hizla küreselleşen dünyaya paralel olarak teknoloji de her geçen zaman diliminde daha da ilerlemektedir. Eğitim sistemini bu teknolojik ilerlemeden uzak tutmak düşünülemez. $\mathrm{Bu}$ doğrultuda eğitim kurumlarında bilişim teknolojilerine önderlik edecek kişilerin başında okul yöneticileri gelmektedir. Yöneticilerin teknolojik liderlik becerilerini değerlendirilmesinde önemli paydaşlardan biri öğretmenlerdir. Bu nedenle öğretmenlerin yöneticilerinin teknoloji liderliği rollerine ilişkin görüşleri öğretmenlerin sahip olduğu özellikler/nitelikler açısından incelenmiştir. 


\section{Kaynaklar}

Arslan, S. (2016). Eğitimde teknoloji entegrasyonunu etkileyen faktörlerdeki değişimin incelenmesi. Yayımlanmamış Yüksek Lisans Tezi, Eğitim Bilimleri Enstitüsü On Dokuz Mayıs Üniversitesi, Samsun.

Uysal Balaban, N. (2012). Okul yöneticilerinin teknoloji liderliği rolleri ile bilgisayar kaygı düzeyleri arasındaki ilişkinin belirlenmesi. Yayımlanmamış Yüksek Lisans Tezi, Eğitim Bilimleri Enstitüsü Anadolu Üniversitesi, Eskişehir.

Baş, E.D. (2012). İlköğretim okulu yöneticilerinin teknoloji liderliği rolleriyle okul iklimi arasındaki ilişki. Yayımlanmamış Yüksek Lisans Tezi, Sosyal Bilimler Enstitüsü Maltepe Üniversitesi, İstanbul.

Creighton, T. (2003). The principal as technology leader. California: Corwin.

Engür, A. (2014). Teknoloji öğretmenlerinin okul müdürlerinin teknolojik liderlik becerileri hakkındaki görüşleri. Yayımlanmamış Yüksek Lisans Tezi, Eğitim Bilimleri Enstitüsü Akdeniz Üniversitesi, Antalya.

Hayytov, D. (2013). Ĕgitim yöneticilerinin teknoloji liderliği yeterlik algıları ile öğretmenlerin teknolojiye yönelik tutumları arasındaki ilişki. Yayımlanmamış Yüksek Lisans Tezi, Eğitim Bilimleri Enstitüsü Gazi Üniversitesi, Ankara.

Irmak, M. (2015). Illkokul ve ortaokul ögretmenlerinin, yöneticilerinin "teknoloji liderliği”" düzeylerine ilişkin algıları. Yayımlanmamış Yüksek Lisans Tezi, Eğitim Bilimleri Enstitüsü Pamukkale Üniversitesi, Denizli.

Karasar, N. (1999). Bilimsel araştırma yöntemi. (9. Baskı). Ankara: Nobel.

Küplü, N. (2012). Devlet ilkögretim ve özel ilköğretim okullarının teknoloji yeterlilikleri ve bu okullarda görev yapan sinıf ögretmenlerinin bilgi teknolojileri okuryazarlık düzeylerinin karma metot yöntemiyle değerlendirilmesi (Çanakkale İli Örneği) Yayımlanmamış Yüksek Lisans Tezi, Eğitim Bilimleri Enstitüsü Pamukkale Üniversitesi, Denizli.

Ölçek, G. (2014). İlköğretim okullarında görev yapan okul müdürlerinin teknoloji liderliği düzeylerine ilişkin okul müdürü ve ögrretmenlerinin görüşlerinin incelenmesi. Yayımlanmamış Yüksek Lisans Tezi, Sosyal Bilimler Enstitüsü Uşak Üniversitesi, Uşak. 
Öztaş, A. (2013). Resmi ortaöğretim okulu yöneticilerinin teknoloji liderliği rollerine ilişkin ögrretmen görüşleri. Yayımlanmamış Yüksek Lisans Tezi, Eğitim Bilimleri Enstitüsü Marmara Üniversitesi, İstanbul.

Sincar, M. (2009). İlköğretim Okulu Yöneticilerinin Teknoloji Liderliği Rollerine İliskin Bir Inceleme (Gaziantep İli Örneği). Yayımlanmamış Doktora Tezi, Sosyal Bilimler Enstitüsü İnönü Üniversitesi, Malatya.

Sincar, M. ve Aslan, B.(2011). İlköğretim öğretmenlerinin okul yöneticilerinin teknoloji liderliği rollerine ilişkin görüşleri. Gaziantep Üniversitesi Sosyal Bilimler Dergisi, 10(1), $571-595$.

Sincar, M. (2013). Challenges School Principals Facing in the Context of Technology Leadership. Educational Sciences: Theory \& Practice, 13(2), 1273-1284.

Tahaoğlu, F. ve Gedikoğlu, T. (2009). İlköğretim okulu müdürlerinin liderlik rolleri. Kuram ve Uygulamada Ë̆itim Yönetimi, 15(58), 274-298.

Tunçer, P. (2011). Örgütsel değişim ve liderlik. Sayıştay Dergisi, 80, 57-83. 


\section{Summary}

\section{Problem Statement}

Technology is the integral part of today's world and it directly impacts many areas such as science, culture, health. One and important area of this impact is education and schools. Especially Z generation, who are born in technology and grow with it, force schools to consider the use of technology to satisfy their needs, motivation etc. On the other hand many researches reveal positive impact of the integration of technology in learning teaching processes. The integration of technology in educational settings to improve effective learning of students need well trained teachers and administrators at fist hand. $\mathrm{Bu}$ it is clearly known that if school administrators do not support the use of technology and encourage teachers in schools the new development and implementations of the technology to educational settings will not be stable and affective. School administrators are expected to be the leaders of technology to adapt and implement new technological improvement to their schools and lead the teachers to use the technology for the improvement of their students based on the goals of the curriculum. Being a technology leader, a school administrator should closely follow the technological developments and the reflections of these developments to school so as he/she can provide and establish necessary infrastructure. It is important and necessary to know the technology leadership roles (/qualifications) of school administrators to understand the use, and probably some obstacles of using it, of technology in schools/classes by teachers. School administrators' technology leadership roles can be identified/evaluate in many ways. One can be school administrators perceptions toward themselves, the other can be observations of researchers/experts and the third one is the teacher views toward the technology leadership roles of their administrator. Views of teachers toward the technology leadership roles of their administrator are taken into considerations in this research.

\section{Purpose of the Study}

The main aim of this study is to evaluate the technology leadership roles of the administrators at primary, middle and high school level state schools in accordance with the teachers' views. The study examined the differences of the teachers' views according to their sexes, branches, years of teaching experience, whether they received any training of technology, the type of school they worked at etc. 


\section{Method}

The study is a comparative survey to evaluate the technology leadership roles of the administrators at primary and secondary level state schools. The sample of this study consists of 452 teachers, who are working in Van (a city in eastern part of Turkey), selected via convenience sampling. The teachers forming the sample of the research [male n: 222 (46,9\%); female n:240 (53,1\%)] were chosen from 16 primary/middle and 21 high schools in Van to assure the generalizability of the results. School Principals’ Technology Leadership Role Scale developed by Sincar (2009) was used to collect the research data. The scale has four sub scales: (1) Human centered, (2) Vision, (3) Communication and cooperation and (4) Support. The statistical analyses were performed after testing the normality distribution. Depending on the normality of the distribution parametric (independent t-test; One Way ANOVA) or nonparametric (Kruskal Wallis, Mann Whitney U) tests were preferred to make comparisons.

\section{Findings and Discussion}

School administrators' technology leadership roles found as $\bar{x}: 3,25$ in human centered, $\bar{x}: 3,22$ in Vision, $\bar{x}: 3,14$ in communication and cooperation, $\bar{x}: 3,37$ in support sub scales. These means reveals that teachers think that their school administrators show technology leadership roles at moderate level in vision and a little higher than moderate level in human centered, communication and cooperation, support sub scales. No significant differences $\left(\mathrm{t}_{(450)}=0,55\right.$, $\mathrm{p}>0,05)$ were found between male $(\bar{x}: 3,27)$ and female $(\bar{x}: 3,21)$ teachers' views toward the technology leadership roles of their administrators. The findings revealed that no statistical differences $\left(\mathrm{F}_{(4-447)}=1,76 ; \mathrm{p}>0,05\right)$ were found depending on teachers' subject fields (science, social fields etc.). Statistically significant differences $\left(x^{2}=37,52 ; p<, 01\right)$ were found among the teachers' views toward the technology roles of their administrators in terms of the types of school where teachers work. Based on these results, Mann Whitney U analysis revealed primary school teachers' views were more positive than middle and high school teachers. Middle school and vocational technical high school teachers had the lowest arithmetic mean scores toward their administrator technology leadership roles among all school types. No significant differences were found among teachers' views depending on their seniority, having an in-service training related to technology in education and having a postgraduate degree. Significant differences were found among teachers' views depending on their perceptions toward their schools' level of technology infrastructure satisfactory. The finding revealed that 
teachers who found their schools' level of technology infrastructure unsatisfactory had negative views toward the technology leadership roles of their administrator compared to the ones who found their schools' level of technology infrastructure satisfactory.

\section{Conclusions and Recommendations}

Teachers' views toward technology leadership roles of their school administrators were found at moderate level in general. In $21^{\text {st }}$ century it is expected that school administrators should have more technology leadership roles to lead and encourage teachers integrating technology in to their teaching learning environments. The result revealed that as the schools have more technologic opportunities, teachers perceive their administrator capable of showing their technology leadership roles better. Basing on these results, first of all the schools should be equipped with modern technologies which give an opportunity to school administrator to show their technology leadership potential. The results reveal that in service training has no effect on the potential of school administrators' technology leadership so school administrators should have well designed, effective in service training programs to improve their technology literacy and understanding of integrating technology to school environment.

Keywords: Leadership, technology leadership, school administrator 